\title{
KEWENANGAN PRAPERADILAN SEBAGAI SARANA MENCARI KEADILAN BAGI TERSANGKA DALAM SISTEM PERADILAN PIDANA DI INDONESIA (Studi Kasus Praperadilan Nomor: 24/Pid.pra/20 b18/Jaksel)
}

\author{
Sonia Sanuarija
}

Universitas Andalas, Padang, Indonesia

Sanuarijasonia@yahoo.com

Received:03-03-2019; Revised:13-05-2019; Accepted: 18-05-2019

\begin{abstract}
The current abuse of authority can be said as a portrait of law enforcement in Indonesia, where several cases of pretrial applications have been found that have been used as a means to achieve justice for suspects and/or defendants. The consequence of this is the obligation of a judge to make a discovery of the legal vacuum that has occurred. Based on one of the principles of law, namely: Ius Curia Novit, where a judge may not refuse a case given to him on the grounds that there are no legal regulations governing it, it is clear that the judge must fulfill the need for legal vacancies according to the applicable legal system.
\end{abstract}

Keywords: Pretrian, Justice, Criminal Justice System

ABSTRAK

Penyalahgunaan wewenang yang terjadi pada saat ini dapat dikatakan sebagai potret penegakan hukum di Indonesia, dimana telah ditemukan beberapa kasus permohonan praperadilan yang telah dimanfaatkan sebagai sarana untuk mencapai keadilan bagi tersangka dan atau terdakwa. Konsekuensi dari hal tersebut adalah kewajiban dari seorang hakim untuk melakukan penemuan atas kekosongan hukum yang terjadi. Berdasarkan salah satu asas ilmu hukum yaitu: Ius Curia Novit, dimana hakim tidak boleh menolak perkara yang diberikan kepadanya dengan alasan tidak adanya peraturan hukum yang mengaturnya, oleh sebab itu jelaslah bahwa hakim harus memenuhi kebutuhan akan kekosongan hukum tersebut menurut sistem hukum yang berlaku dan ditetapkan.

Kata Kunci: Praperadilan, Keadilan, Sistem Peradilan Pidana.

\section{A. Pendahuluan}

Pasal 1 Ayat (3) Undang-Undang Dasar 1945 menyatakan bahwa Indonesia adalah negara hukum. Dalam sebuah negara hukum terdapat beberapa ciri khas antara lain: Pertama, adanya pengakuan dan perlindungan terhadap hak-hak asasi manusia yang mengandung persamaan dalam bidang politik, hukum, sosial, ekonomi dan kebudayaan. Kedua, adanya peradilan yang bebas dan tidak memihak serta tidak dipengaruhi oleh suatu kekuasaan atau kekuatan apapun juga. Ketiga, legalitas dalam arti hukum dalam segala bentuknya. ${ }^{1}$ Franz Magnis Suseno juga mengemukakan lima ciri negara hukum, yaitu: ${ }^{2}$

\footnotetext{
${ }^{1}$ Mustafa Kamal Pasha, 2003, Pancasila Dalam Tinjauan Historis dan Filosofis, Yogyakarta, Citra Karsa Mandiri, hlm.15

${ }^{2}$ Frans Magnis Suseno, 1988, Etika Politik, Jakarta, Gramedia, hlm.10
} 
1. Fungsi kenegaraan dijalankan oleh lembaga yang bersangkutan sesuai dengan ketetapan sebuah Undang-Undang Dasar.

2. UUD menjamin hak asasi manusia yang paling penting, karena tanpa jaminan tersebut, maka hukum akan menjadi sarana penindasan.

3. Badan-badan negara selalu menjalankan kekuasaan masing-masing dan hanya taat pada dasar hukum yang berlaku.

4. Terhadap tindakan badan negara, masyarakat dapat mengadu ke pengadilan.

5. Badan kehakiman bebas dan tidak memihak.

Beberapa ciri khas dari negara hukum di atas, dapat disimpulkan bahwa keberadaan suatu negara hukum pada dasarnya ditujukan untuk mencapai apa yang menjadi tujuan hukum yaitu, menegakkan keadilan yang tidak boleh ditinggalkan oleh warga negara, penyelenggara negara, lembaga kenegaraan, dan lembaga kemasyarakatan baik di daerah maupun di pusat. Dalam hal ini bisa diwujudkan salah satunya dalam hukum acara pidana. Hukum acara pidana mempunyai tugas pokok, yaitu: mencari dan menemukan kebenaran, pengambilan keputusan oleh hakim, dan pelaksanaan putusan hakim.

Putusan hakim adalah putusan akhir dari suatu pemeriksaan persidangan di pengadilan dalam suatu perkara. Putusan hakim pada akhir suatu sengketa pada umumnya mengandung sanksi berupa hukuman terhadap pihak yang dikalahkan. Sanksi hukuman ini dapat dipaksakan kepada pihak yang melanggar hak, berupa pemenuhan prestasi dan atau pemberian ganti rugi kepada pihak yang telah dirugikan atau dimenangkan. ${ }^{3}$ Hal ini tentu saja menjadi tujuan dari hukum acara pidana, di mana hukum acara pidana mempunyai tujuan untuk mengejar kebenaran dan pemeriksaan pidana, sebab dengan kebenaran inilah yang dijadikan dan dasar dari suatu putusan hakim pidana. ${ }^{4}$

Dalam upaya mengejar kebenaran dan pemeriksaan pidana atas suatu tindak pidana, terdapat beberapa asas yang salah satunya adalah asas praduga tak bersalah yang harus diterapkan oleh aparat penegak hukum, dan merupakan asas terpenting dalam hukum acara pidana. Asas ini dimuat dalam Pasal 8 Undang-Undang No.48 Tahun 2009 tentang Ketentuan-Ketentuan Pokok Kekuasaan Kehakiman. Asas praduga tak bersalah adalah: tiap orang yang disangka, ditangkap, ditahan, dituntut, dan atau dihadapkan di depan pengadilan wajib dianggap tidak bersalah sebelum adanya putusan pengadilan yang menyatakan kesalahannya dan telah memperoleh kekuatan hukum tetap. ${ }^{5}$

Sebagai seorang yang belum dinyatakan bersalah, maka wajar bila tersangka atau terdakwa mendapatkan jaminan perlindungan hak yang diatur dalam Kitab UndangUndang Hukum Acara Pidana, seperti hak untuk segera mendapatkan pemeriksaan dalam taraf penyidikan, hak segera mendapat pemeriksaan oleh pengadilan dan mendapat putusan yang seadil-adilnya, hak pemberitahuan tentang tindak pidana yang disangkakan atau dituduhkan kepadanya, hak menyiapkan pembelaan, hak bantuan hukum maupun hak mendapat kunjungan. Hak tersangka atau terdakwa sesuai dengan tujuan KUHAP yang memberikan perlindungan kepada hak-hak asasi dalam keseimbangan dengan kepentingan umum. ${ }^{6}$

Sehubungan dengan hak-hak tersangka, maka lahirlah lembaga baru dalam KUHAP yang disebut praperadilan. Praperadilan merupakan hal baru dalam dunia peradilan Indonesia. Praperadilan merupakan salah satu lembaga baru yang diperkenalkan di dalam Undang-Undang Nomor 8 tahun 1981 tentang Hukum Acara Pidana (KUHAP) di tengahtengah kehidupan penegakan hukum. Praperadilan dalam KUHAP di tempatkan di dalam

\footnotetext{
${ }^{3}$ R.Soeroso, 2011, Pengantar Ilmu Hukum, Jakarta, Sinar Grafika, hlm. 25

${ }^{4}$ Andi Hamzah, 2002, Hukum Acara Pidana, Jakarta: Sinar Grafika, hlm.8

${ }^{5}$ Ibid.

${ }^{6}$ Loebby Luqman, 2002, Pra Peradilan di Indonesia, Jakarta, Ghalia Indonesia, hlm. 18
} 
Bab X, Bagian kesatu, sebagai salah satu bagian ruang lingkup wewenang mengadili bagi Pengadilan Negeri. ${ }^{7}$

Di Eropa dikenal lembaga semacam itu, tetapi fungsinya memang benar-benar melakukan pemeriksaan pendahuluan. Jadi fungsi hakim komisaris (Rechter commisaris) di Belanda dan Judge d'Instruction di Prancis benar-benar dapat disebut praperadilan, karena selain menentukan sah atau tidaknya penangkapan, penahanan dan penyitaan, juga melakukan pemeriksaan pendahuluan atas suatu perkara. ${ }^{8}$ Misalnya, penuntut umum di Belanda dapat minta pendapat hakim mengenai suatu kasus, apakah misalnya kasus itu pantas dikesampingkan dengan transaksi (misalnya perkara tidak diteruskan ke persidangan dengan mengganti kerugian) ataukah tidak. Meskipun ada kemiripan dengan hakim komisaris itu, namun wewenang praperadilan itu terbatas. Wewenang untuk memutuskan apakah penangkapan atau penahanan sah ataukah tidak. Apakah penghentian penyidikan atau penuntutan sah ataukah tidak. Tidak disebut apakah penyitaan sah atau tidak. $^{9}$

Menurut Oemar Seno Adji, lembaga rechter commissaris yang memimpin pemeriksaan pendahuluan muncul sebagai perwujudan keaktifan hakim, yang di Eropa Tengah mempunyai posisi penting yang mempunyai kewenangan untuk menangani upaya paksa (dwang middelen), penahanan, penyitaan, penggeledahan badan, rumah, dan pemeriksaan surat-surat. ${ }^{10}$

Di Indonesia, praperadilan tidak mempunyai wewenang seluas itu dan tidak terdapat ketentuan dimana hakim praperadilan melakukan pemeriksaan pendahuluan atau memimpinnya. Kehadiran lembaga praperadilan bukan merupakan lembaga peradilan tersendiri. tetapi hanya merupakan pemberian wewenang dan fungsi baru yang dilimpahkan KUHAP kepada setiap Pengadilan Negeri, sebagai wewenang dan fungsi tambahan Pengadilan Negeri yang telah ada selama ini. kalau selama ini wewenang dan fungsi Pengadilan Negeri adalah mengadili dan memutus perkara pidana dan perkara perdata sebagai tugas pokok, maka terhadap tugas tadi diberi tugas tambahan untuk menilai hal-hal yang diatur sebagai aspek praperadilan. ${ }^{11}$

Praperadilan di atur dalam Pasal 1 Butir 10, dan dipertegas lagi dalam Pasal 77 Huruf (a), sampai dengan Pasal 83 Kitab Undang-Undang Hukum Acara Pidana. Pasal 77 Huruf (a) Kitab Undang-Undang Hukum Acara Pidana menyatakan, bahwa: KUHAP mengatur kewenangan praperadilan hanya sebatas pada sah atau tidaknya penangkapan, penahanan, penghentian penyidikan atau penuntutan, maka melalui putusan ini Mahkamah Konstitusi memperluas ranah praperadilan termasuk sah atau tidaknya penetapan tersangka, penggeledahan, dan penyitaan.

Pasal 83 Ayat (1) Kitab Undang-Undang Hukum Acara Pidana menyatakan, bahwa: terhadap putusan praperadilan dalam hal sebagaimana dimaksud dalam Pasal 79, Pasal 80, dan Pasal 81 tidak dapat dimintakan banding, sedangkan pada Pasal 83 Ayat (2) Kitab Undang-Undang Hukum Acara Pidana menyatakan, bahwa: Dikecualikan dari ketentuan Ayat (1) adalah putusan praperadilan yang menetapkan tidak sahnya penghentian penyidikan atau penuntutan, hal itu dapat dimintakan putusan akhir ke pengadilan tinggi.

Pra Peradilan merupakan salah satu dari bagian ruang lingkup wewenang mengadili bagi pengadilan negeri. Berdasarkan Pasal 1 Butir 10 KUHAP, praperadilan adalah

${ }^{7}$ M. Yahya Harahap, 2010, Pembahasan Permasalahan dan Penerapan KUHAP (Pemeriksaan Sidang Pengadilan, Banding, Kasasi, dan Peninjauan Kembali), Jakarta, Sinar Grafika., hlm. 1

${ }^{8}$ Andi Hamzah, 2008, Hukum Acara Pidana Indonesia,Jakarta, Sinar Grafika, hlm. 187

${ }^{9}$ Ibid.

${ }^{10}$ Ibid, hlm. 188

${ }^{11}$ M. Yahya Harahap, 2010, Op.Cit. 
wewenang pengadilan negeri untuk memeriksa dan memutuskan menurut cara yang sah yang diatur di dalam Undang-Undang ini tentang:

1. Sah atau tidaknya suatu penangkapan dan/atau penahanan atas permintaan tersangka atau keluarganya atau pihak lain atas kuasa tersangka.

2. Sah atau tidaknya penghentian penyidikan atau penghentian penuntutan atas permintaan demi tegaknya hukum dan keadilan.

3. Permintaan ganti kerugian atau rehabilitasi oleh tersangka atau keluarganya atau pihak lain atas kuasanya yang perkaranya tidak diajukan ke pengadilan.

Maksud dan tujuan lembaga peradilan adalah tegaknya hukum dan perlindungan hak asasi tersangka dalam tingkat pemeriksaan penyidikan dan penuntutan. Dengan adanya lembaga praperadilan, maka tersangka dilindungi dalam pemeriksaan pendahuluan terhadap tindakan-tindakan kepolisian dan atau kejaksaan yang melanggar hukum dan merugikan tersangka. Seseorang yang dikenakan penangkapan, penahanan dan atau tindakan lain yang dilakukan secara tidak sah, yaitu tidak memenuhi syarat yang ditentukan oleh undang-undang, maka tersangka atau terdakwa atau keluarganya atau pihak lain yang mendapat kuasa (penasehat hukum) dapat meminta pemeriksaan dan putusan oleh hakim tentang tidak sahnya penangkapan atau penahanan serta tindakantindakan lain atas dirinya tersebut. Disamping itu, praperadilan sebagai lembaga baru berfungsi sebagai alat kontrol dari penyidik terhadap penyalahgunaan wewenang yang diberikan kepadanya. ${ }^{12}$

Penyalahgunaan wewenang juga dapat dilihat berdasarkan putusan Mahkamah Konstitusi Nomor 21/PUU-XII/2014 mengabulkan permohonan terpidana kasus korupsi proyek biomediasi PT. Chevron Bachtiar Abdul Fatah mengenai sah atau tidaknya status tersangka seseorang. Putusan MK ini dikeluarkan pada tanggal 28 April 2015, seiring dengan keputusan hakim Sarpin Rizaldi yang telah keluar sebelumnya yang dinilai terlalu berani mengambil pandangan yang berbeda dengan hukum lainnya yang sangat formalistik dengan menyatakan penetapan tersangka masuk dalam yurisdiksi Praperadilan yang diajukan Komisaris Jenderal Budi Gunawan atas penetapannya sebagai tersangka yang diajukan oleh KPK. ${ }^{13}$

Putusan praperadilan Nomor 04/Pid.Prap/2015/PN.Jkt. Sel oleh hakim tunggal Sarpin Rizaldi yang dikeluarkan pada tanggal 16 Februari 2015 telah berhasil menuai pro kontra dalam masyarakat, termasuk juga bagi kalangan praktsi dan akademisi. Dalam putusannya hakim Sarpin memutuskan bahwa penetapan status tersangka terhadap Budi Gunawan dinyatakan tidak sah. Posisi kasusnya adalah Komisaris Jenderal Budi Gunawan sebagai pemohon dan termohonnya adalah Komisi Pemberantasan Korupsi. Di dalam permohonannya Budi Gunawan sebagai pemohon menganggap bahwa objek pra peradilan sebagaimana yang diatur dalam Pasal 77 KUHAP merupakan tindakan penyidik atau penuntut umum dalam rangka menjalankan wewenangnya yang dilakukan tanpa alasan hukum atau cacat hukum, sehingga melanggar martabat kemanusiaan seseorang, termasuk menentukan status tersangka yang merupakan salah satu proses dari sistem penegakan hukum pidana yang harus dilakukan sesuai dengan prosedur yang ada di dalam KUHAP.

Di awal tahun 2018 juga ditemukan kasus praperadilan dalam pengadaan E-KTP dengan tersangka Setia Novanto. Hakim Kusno menyatakan bahwa gugatan praperadilan yang diajukan Ketua non aktif DPR Setia Novanto terhadap Komisi Pemberantasan

\footnotetext{
12. S.Tanusubroto, 1983, Peranan Pra Peradilan Dalam Hukum Acara Pidana, Bandung, Alumni, hlm. 30

${ }^{13}$ http://makassar.lan.go.id/index.php/survei/refleksi/750-putusan-mk-penetapan-tersangkapenggeledehan-dan-penyitaan-masuk-dalam-ranah-hukum-praperadilan, diakses pada tanggal 4 November 2016.
} 
Korupsi dinyatakan gugur. Salah satu pertimbangannya, praperadilan tersebut gugur setelah persidangan pokok perkara kasus proyek E-KTP, di mana Novanto duduk selaku terdakwa, telah mulai diperiksa di periksa di Pengadilan Tinggi Korupsi Jakarta. Merujuk pada Pasal 82 Ayat 1 Huruf d Undang-Undang Nomor 8 Tahun 1981 (KUHAP) menyatakan bahwa: Dalam hal suatu perkara sudah mulai diperiksa oleh pengadilan negeri, sedangkan pemeriksaan mengenai permintaan kepada praperadilan belum selesai, maka permintaan tersebut dinyatakan gugur. ${ }^{14}$

Menurut Hakim Kusno aturan ini telah diperjelas pada putusan Mahkamah Konstitusi (MK) Nomor 102/PUU-XII/2015, dan membebankan biaya perkara kepada pemohon sebesar nihil, jadi demikian penetapan sudah dijelaskan bahwa pada hakikatnya hukum positif sudah jelas, permohonan pra peradilan dinyatakan gugur dan terhadap praperadilan ini sudah tidak memungkinkan dilakukan upaya hukum. Jaksa KPK sebelumnya sudah membacakan dakwaan terhadap Setya Novanto, yang didakwa menyalahgunakan kewenangan selaku anggota DPR dalam proyek pengadaan Kartu Tanda Penduduk berbasis elektronik. Perbuatan Novanto tersebut menyebabkan kerugian negara $\mathrm{Rp}$ 2,3 Trilliun dari total nilai proyek 5.9 Trilliun. Menurut Jaksa, Novanto secara langsung atau tidak langsung mengintervensi proses penganggaran serta pengadaan barang dan jasa dalam proyek E-KTP pada tahun 2011-2013. Penyalahgnaan kewenangan itu dilakukan dengan tujuan untuk memperkaya diri sendiri, serta memperkaya orang lain dan korporasi. ${ }^{15}$

Novanto didakwa telah memperkaya diri sendiri sebanyak 7.3 juta dollar Amerika Serikat tersebut berasal dari perusahaan anggota konsorsium yang sengaja dimenangkan dalam lelang proyek E-KTP. Selain itu Novanto juga diperkaya dengan mendapatkan jam tangan merek Richard Mille seri RM 011 seharga 135 dollar AS atau sekitar Rp. 1,3 Milliar (Kurs 2010), dan Novanto didakwa melanggar Pasal 2 Ayat 1 atau Pasal 3 Undang-Undang Nomor 31 Tahun 1999 sebagaimana diubah dalam Undang-Undang Nomor 20 Tahun 2001 tentang Pemberantasan Tindak Pidana Korupsi jo Pasal 55 Ayat (1) KUHP. ${ }^{16}$

Kasus praperadilan selanjutnya dengan bunyi putusan praperadilan pada 10 April 2018 adalah, "Memerintahkan termohon untuk melakukan proses hukum selanjutnya sesuai dengan ketentuan hukum dan peraturan perundang-undangan yang berlaku atas dugaan tindak pidana korupsi Bank Century dalam bentuk melakukan penyidikan dan menetapkan tersangka terhadap Boediono, Muliaman D Hadad, Raden Pardede dkk (sebagaimana tertuang dalam surat dakwaan atas nama terdakwa Budi Mulya) atau melimpahkannya kepada kepolisian dan atau kejaksaan untuk dilanjutkan dengan penyelidikan, penyidikan dan penuntutan dalam proses persidangan di Pengadilan Tipikor Jakarta Pusat. ${ }^{17}$

Putusan praperadilan adalah putusan akhir yang tidak bisa diupayakan hukum banding (Pasal 83 KUHAP), dan Mahkamah Agung (MA) tak dapat melakukan Peninjauan Kembali (Pasal 3 Peraturan Mahkamah Agung Republik Indonesia Nomor 4 Tahun 2016), karenanya, putusan pra peradilan adalah putusan yang incracht. KPK

${ }^{14}$ https://nasional.kompas.com, Hakim Gugurkan Gugatan Pra Peradilan Setya Novanto, diakses pada tanggal 2 Mei 2018

${ }^{15}$ Ibid.

${ }^{16}$ Ibid

${ }^{17}$ https://nasional.sindonews.com/read/1299034/18/bagaimana-kpk-menyikapi-putusanpraperadilan-1524088716, Bagaimana KPK Menyikapi Putusan Praperadilan?, diakses pada tanggal 2 Mei 2018. 
sebagai penegak hukum, maka dedikasi dan komitmen yang utama di pundaknya adalah menegakkan hukum. Sebagai penegak hukum KPK harus menegakkan putusan praperadilan sebagai sebuah hukum. Berdasarkan Pasal 17 Huruf c Undang-Undang Nomor 30 Tahun 2014 tentang Administrasi Pemerintahan, pejabat yang tidak melaksanakan putusan pengadilan yang telah memperoleh kekuatan hukum tetap, dipandang telah bertindak sewenang-wenang. Bertindak sewenang-wenang artinya telah meninggalkan akal sehat dan keluar dari norma. Ini adalah hal yang sangat ironis jika sampai terjadi, penegak hukum tidak lagi dalam rule of law. ${ }^{18}$

Putusan praperadilan ini bukan putusan yang pertama. Sudah kali keempat pemohon mengajukan permohonan yang sama. Putusan praperadilan Nomor 24/Pid.Pra/2018/PN.Jaksel sebelumnya telah memutuskan yang amarnya "Memerintahkan termohon untuk melakukan proses hukum selanjutnya sesuai dengan ketentuan hukum dan peraturan perundang-undangan yang berlaku atas dugaan tindak pidana korupsi Bank Century dalam bentuk melakukan penyelidikan dan/atau penyidikan." Dengan begitu, putusan praperadilan 2018 ini harus dibaca sebagai pemenuhan harapan pencari keadilan akan tidak kunjung dipenuhinya perintah hukum oleh penegak hukum. Pengadilan tidak mungkin hanya akan terus memerintahkan pada perintah yang sama dengan putusan sebelumnya tanpa berkesudahan sampai pra peradilan kesekian kalinya. ${ }^{19}$

Publik perlu mengapresiasi keberanian hakim untuk menghentikan ketidakpastian hukum ini yang dapat dinilai bahwa tidak ada iktikad baik untuk melanjutkan penanganan perkara bailout Bank Century pada nama yang lain. Keengganan untuk melanjutkan penyidikan pada nama lainnya tersebut dapat dinilai sebagai keputusan fiksi negatif (menolak melanjutkan) penyidikan kepada nama lainnya.Ketidakpastian hukum yang diputus oleh hakim. Sorotan banyak pihak hanya fokus pada soal mengapa hakim "memerintahkan menetapkan sebagai tersangka". Publik juga harus tahu bahwa hal ini merupakan konsekuensi dari dakwaan jaksa: bahwa terdakwa Budi Mulya bersama-sama Boediono, Miranda S Gultom, Siti C Fajriyah, Budi Rohadi, Muliaman D hadad, Hartadi Agus, Ardhayadi M, dan Raden Pardede telah melakukan atau turut serta melakukan beberapa perbuatan yang ada hubungannya sedemikian rupa sehingga harus dipandang sebagai perbuatan berlanjut. Konsekuensi didakwanya Budi Mulya melakukan tindak pidana bersamasama dengan beberapa orang (deelneming) berdasarkan Pasal 55 ayat (1) KUHP tersebut mengandung perintah setiap peserta dalam tindak pidana tersebut harus diperlakukan sama sebagai pelaku atas tindak pidana yang didakwakan.

Jika sampai hukum memutus berbeda antar para peserta delneeming dimaksud, hal itu bisa menjadi pintu peninjauan kembali, yang salah satu alasannya yakni, "Apabila antara pihak-pihak yang sama mengenai suatu soal yang sama, atas dasar yang sama oleh pengadilan yang sama atau sama tingkatnya telah diberikan putusan yang bertentangan satu dengan yang lain,” demikian Pasal 67 Undang-Undang Nomor 5 Tahun 2004 tentang Mahkamah Agung. Inilah kepentingan hukum untuk menghukumi secara sama pihakpihak yang turut serta. Apalagi dalam kasus bailout Bank Century ini kapasitas Budi Mulya berkapasitas sebagai Deputi Gubernur Bank Indonesia Bidang 4, Pengelolaan Moneter dan Devisa dan Kantor Perwakilan (KPW). Posisinya bukan kunci, sementara yang disebut dalam dakwaan lain tersebut Gubernur BI Boediono, Deputi Gubernur Senior Miranda Goeltom, Deputi Gubernur Bidang Kebijakan Perbankan/Stabilitas Sistem Keuangan Muliaman Hadad, dkk. Pihak-pihak inilah yang memiliki posisi lebih kunci dalam pengambilan keputusan mengeluarkan kebijakan bailout Bank Century. Dalam

\footnotetext{
18 Ibid.

19 Ibid.
} 
penegakan hukumnya, Budi Mulya telah berproses hukum sampai kasasi, tetapi namanama yang tersebut dalam dakwaan KPK itu oleh KPK malah tidak kunjung disidik. Ini ketidakadilan yang nyata, minimal secara formal diperlakukan dalam proses hukum. Karena itu, hilang alasan KPK untuk berdalih masih mencari alat bukti, karena dakwaan "bersama-sama melakukan tindak pidana" itu dari jaksa KPK. KPK pun tak dapat berdalih bahwa itu merupakan dakwaan produk sebelumnya. KPK adalah penegak hukum, karenanya pandangan hukumnya secara kelembagaan haruslah konsisten. Tidak karena perubahan struktur KPK lalu mengubah pandangan hukumnya.

Berdasarkan beberapa uraian kasus di atas, maka dapat disimpulkan bahwa: Penyalahgunaan wewenang yang terjadi pada saat ini dapat dikatakan sebagai potret penegakan hukum di Indonesia, dimana telah ditemukan beberapa kasus permohonan praperadilan yang telah dimanfaatkan sebagai sarana untuk mencapai keadilan bagi tersangka dan atau terdakwa. Konsekuensi dari hal tersebut adalah kewajiban dari seorang hakim untuk melakukan penemuan atas kekosongan hukum yang terjadi. Berdasarkan salah satu asas ilmu hukum yaitu: Ius Curia Novit, dimana hakim tidak boleh menolak perkara yang diberikan kepadanya dengan alasan tidak adanya peraturan hukum yang mengaturnya, oleh sebab itu jelaslah bahwa hakim harus memenuhi kebutuhan akan kekosongan hukum tersebut menurut sistem hukum yang berlaku dan ditetapkan.

Asas lain yang harus dibahas adalah Res Judicate Pro Veritate Habetur. Apa yang telah diputus oleh hakim harus dianggap benar. Merespons putusan praperadilan Pengadilan Negeri Jakarta Selatan soal kasus bailout Bank Century yang memerintahkan termohon Komisi Pemberantasan Korupsi (KPK) melanjutkan penyidikan dan menetapkan Boediono sebagai tersangka, banyak pihak yang berbeda pendapat. Perbedaan pandangan itu wajar, bahkan seandainya 1.000 ahli hukum pun boleh berpendapat 1001 dari berbagai sudut pandang, apalagi jika dikaitkan dengan aspek sosial dan politik. Namun, bagaimanapun pemutusnya adalah hakim. Ruang perdebatan baik di ranah publik maupun di ruang akademis tetaplah sebagai pandangan sementara. Putusan hakim adalah hukum dalam arti konkret. Putusan hakim apa pun harus dipandang sebagai benar dan berlaku sebagai hukum. Itulah konsekuensi kita sebagai bangsa memilih negara berdasarkan hukum. ${ }^{20}$

Pasal 22 Algemene Berpalingen Van Wetgeving Voor Indonesie yang disingkat $A B$ yang sampai saat ini masih berlaku berdasarkan Pasal II Aturan Peralihan Undang-undang Dasar Negara Republik Indonesia Tahun 1945, bahwa hakim yang menolak untuk menyelesaikan suatu perkara dengan alasan bahwa peraturan perundang undangan yang bersangkutan tidak menyebutkan, tidak jelas atau tidak lengkap, maka ia dapat dituntut untuk dihukum karena menolak mengadili. Kesimpulan dari ketentuan di atas adalah seorang hakim mempunyai hak dan kewajiban untuk membuat sebuah peraturan untuk menyelesaikan sebuah perkara apabila tidak ditemukan aturan atau kebiasaan yang mengatur hal tersebut. Jika hakim menolak perkara tersebut maka ia bisa dituntut dan sanksi pidana berlaku baginya.

Berdasarkan ketentuan Pasal 10 Ayat (1) Undang-Undang Nomor 48 Tahun 2009 tentang Kekuasaan Kehakiman, Pengadilan dilarang menolak untuk memeriksa, mengadili, dan memutus suatu perkara yang diajukan dengan dalih bahwa hukum tidak ada atau kurang jelas, melainkan wajib untuk memeriksa dan mengadilinya. Ketentuan ini makin memperkuat kewajiban hakim dalam melakukan penemuan hukum, dimana hasil dari penemuan hukum tersebut yang berupa putusan dinamakan yurisprudensi. Yurisprudensi

20 https://nasional.kompas.com, Hakim Gugurkan Gugatan Pra Peradilan Setya Novanto, diakses pada tanggal 2 Mei 2018. 
yang merupakan salah satu diantara beberapa sumber hukum lainnya adalah keputusan hakim terdahulu yang sering diikuti dan dijadikan dasar keputusan oleh hakim kemudian mengenai masalah yang sama. Putusan tersebut boleh diikuti oleh hakim yang sependapat dengan yurisprudensi tersebut mengenai perkara yang serupa, tidak terdapat peraturan yang mewajibkan hakim lain untuk memberikan putusan serupa namun kembali tergantung kepada keyakinan hakim tersebut yang menjadikan yurisprudensi tersebut tak lebih dari sebagai pedoman bagi tersangka untuk melakukan upaya hukum-upaya hukum yang tersedia, mencari keadilan maupun sebagai jalan agar terlepas dari tuntutan hukum tanpa harus masuk ke dalam proses peradilan, sehingga tidak terjadi kesatuan pemahaman pada setiap hakim untuk menjatuhkan putusan, seperti putusan Hakim Sarpin. Hal tersebut tentu saja bukan perwujudan daripada tujuan hukum yaitu untuk mencapai keadilan dan kepastian hukum.

Berdasarkan alasan itulah penulis tertarik untuk melakukan penelitian dengan rumusan masalah, apakah dasar pertimbangan bagi hakim dalam memutuskan putusan pra peradilan Nomor 24/Pid.Pra/2018/PN.Jaksel, dan bagaimana implikasi hukum putusan Praperadilan Nomor 24/Pid.Pra/2018/PN.Jaksel. yang dijadikan sebagai yurisprudensi terhadap proses praperadilan dalam upaya pembaruan hukum di masa mendatang (Ius Constituendum).

\section{B. PEMBAHASAN}

\section{Dasar Pertimbangan Bagi Hakim dalam Memutuskan Putusan Pra Peradilan Nomor 24/Pid.Pra/2018/PN.Jaksel.}

Hakim merupakan pejabat negara yang memiliki kewenangan untuk mengadili suatu perkara. Putusan hakim harus memenuhi ketentuan KUHAP dalam Pasal 197 ayat (1) huruf d yakni memuat dasar pertimbangan secara lengkap. Kemudian sebelum mengambil putusan terhadap suatu perkara majelis hakim harus mengadakan rapat permusyawaratan hakim yang bersifat rahasia sesuai dengan ketentuan Pasal 14 ayat (1) dan ayat (2) Undang-Undang Nomor 48 Tahun 2009 tentang Kekuasaan Kehakiman yang berbunyi:

a. Putusan diambil berdasarkan sidang permusyawaratan hakim yang bersifat rahasia.

b. Dalam sidang permusyawaratan, setiap hakim wajib menyampaikan pertimbangan atau pendapat tertulis terhadap perkara yang sedang diperiksa dan menjadi bagian yang tidak terpisahkan dari putusan.

Hakim dalam menjatuhkan putusan ini terdapat 2 (dua) kategori pertimbangan hakim menurut Rusli Muhammad, yaitu:

a. Pertimbangan yang bersifat yuridis

Pertimbangan yang bersifat yuridis adalah pertimbangan hakim yang didasarkan pada fakta yuridis dalam persidangan dan oleh ketentuan undang-undang harus dimuat dalam putusan hakim. Pertimbangan tersebut yaitu:

1) Dakwaan Jaksa Penuntut Umum (JPU), pada dasarnya merupakan dasar penting hukum acara pidana karena berdasarkan hal yang dimuat dalam surat itu, hakim akan memeriksa perkara itu. Dengan demikian, terdakwa hanya dapat dipidana jika terbukti telah melakukan delik yang disebut dalam dakwaan.

2) Keterangan terdakwa, menurut KUHAP dengan jelas mencantumkan "keterangan terdakwa" sebagai alat bukti dalam Pasal 184 butir e, berbeda dengan peraturan lama yaitu HIR yang menyebut "pengakuan terdakwa" sebagai alat bukti menurut Pasal 295. Dapat dilihat dengan jelas bahwa "keterangan terdakwa" sebagai alat bukti tidak perlu sama atau berbentuk pengakuan. Semua keterangan terdakwa hendaknya didengar. Apakah itu berupa penyangkalan, pengakuan, ataupun pengakuan sebagian dari perbuatan atau keadaan. 
3) Keterangan saksi; Keterangan saksi dapat dikategorikan sebagai alat bukti sepanjang keterangan itu mengenai sesuatu peristiwa pidana yang ia dengar sendiri, ia lihat sendiri, alami sendiri, dan harus disampaikan di dalam sidang pengadilan dengan mengangkat sumpah.

4) Barang bukti; Pengertian barang bukti disini adalah semua benda yang dapat dikenakan penyitaan dan diajukan oleh penuntut umum di depan sidang pengadilan, yang meliputi:

a) Benda atau tagihan tersangka atau terdakwa seluruhnya atau sebagian diduga diperoleh dari tindak pidana atau sebagai hasil tindak pidana.

b) Benda yang dipergunakan secara langsung untuk melakukan tindak pidana untuk mempersiapkan.

c) Benda yang digunakan untuk menghalang-halangi penyidikan tindak pidana.

d) Benda lain yang mempunyai hubungan langsung dengan tindak pidana yang dilakukan.

5) Pasal-pasal dalam hukum pidana.

Dalam praktek persidangan, pasal peraturan hukum pidana itu selalu dihubungkan dengan perbuatan terdakwa. Dalam hal ini, penuntut umum dan hakim berusaha untuk membuktikan dan memeriksa melalui alat-alat bukti tentang apakah perbuatan terdakwa telah atau tidak memenuhi unsur-unsur yang dirumuskan da289lm pasal peraturan hukum pidana. Apabila ternyata perbuatan terdakwa memenuhi unsur-unsur dari setiap pasal yang dilanggar, berarti terbuktilah menurut hukum kesalahan terdakwa, yakni telah melakukan perbuatan seperti diatur dalam pasal hukum pidana tersebut.

b. Pertimbangan non yuridis

Pertimbangan yang bersifat non yuridis adalah pertimbangan hakim yang hanya bertitik tolak pada dampak yang merugikan dan merusak tatanan dalam kehidupan bermasyarakat berbangsa dan bernegara. Pertimbangan tersebut yaitu:

1) Latar belakang terdakwa

Latar belakang terdakwa adalah setiap keadaan penyebab timbulnya suatu keinginan serta dorongan keras pada diri terdakwa untuk melakukan tindak pidana.

2) Akibat dari perbuatan terdakwa Akibat dari tindak pidana yang dilakukan terdakwa bagi korban, pihak lain dan masyarakat luas.

3) Kondisi diri terdakwaKondisi terdakwa sebelum melakukan tindak pidana baik kondisi fisik, psikologis, maupun status sosial dari terdakwa.

4) Agama terdakwa

Keterikatan para hakim terhadap ajaran agama tidak cukup hanya dengan kata "ketuhanan" yang terdapat pada kepala sebuah putusan hakim, melainkan harus menjadi ukuran penilaian dari setiap tindakan baik tindakan para hakim itu sendiri maupun tindakan para pembuat kejahatan.

Analisis penulis terhadap dasar pertimbangan hakim dalam Putusan ini dapat dibedakan atas 3 (tiga) dasar yakni:

a. Pertimbangan Filosofis, yang digunakan sebagai dasar pertimbangan oleh hakim dalam menjatuhkan putusan yang dalam pelaksanaannya tetap bersumber pada Pancasila dan Undang-Undang Dasar Negara Republik Indonesia.

b. Pertimbangan Yuridis, meliputi dakwaan jaksa penuntut umum, Keterangan Saksi, Keterangan Terdakwa, Barang Bukti dan pasal-pasal dalam hokum pidana. 
c. Pertimbangan sosiologis, meliputi penjatuhan vonis suatu putusan harus bersumber dengan nilai-nilai kemanusiaan yang ada pada penjabaran sila-sila Pancasila.

Selain pertimbangan tersebut di atas, dalam sebuah putusan haruslah memuat halhal yang memberatkan dan meringankan pidana. Hal ini sesuai dengan ketentuan Pasal 197 ayat (1) huruf f KUHAP yang berbunyi:

"Pasal peraturan perundang-undangan yang menjadi dasar pemidanaan atau tindakan dan peraturan perundang-undangan yang menjadi dasar hukum dari putusan, disertai keadaan yang memberatkan dan yang meringankan terdakwa."

Atas pertimbangan tersebut, maka menurut Majelis Hakim pantas dan dipandang telah memenuhi rasa keadilan. Meskipun penulis dapat memahami semua pertimbangan hakim dalam menjatuhkan pidana terhadap pelaku tindak pidana dapat mempertimbangkan jenis pidana yang tepat untuk dijatuhkan terhadap pelaku tindak pidana, dimana Hukum pidana pada dasarnya bersifat ultimum remedium dimana hukum pidana hendaklah dijadikan upaya terakhir dalam penegakan hukum, sehingga apabila dalam menjatuhkan hukuman maksimum haruslah diterapkan dengan sangat hati-hati kepada terdakwa haruslah dipandang ketika sudah tidak ada lagi terdapat hal-hal yang dapat meringankan hukumannya sehingga dirinya layak untuk mendapatkan hukuman maksimum atas perbuatannya tersebut. Sedangkan masih terdapat hal-hal yang meringankan yang patut dipertimbangkan sebelum menjatuhkan hukuman terhadap diri Terdakwa.

\section{Implikasi Hukum Putusan Praperadilan No. 24/Pid.Pra/2018/PN.Jkt.Sel}

Putusan-putusan praperadilan telah menetapkan bahwa Pasal 77 KUHAP mengenai aspek-aspek Praperadilan tidak mempunyai kekuatan hukum mengikat sepanjang tidak dimaknai termasuk penetapan tersangka, penggeledahan dan penyitaan. Artinya, putusan Mahkamah Konstitusi ini telah memberikan perluasan kewenangan daripada Lembaga Praperadilan itu sendiri.

Berdasarkan Pasal 10 ayat (1) Undang-Undang Nomor 8 tahun 2011 tentang Perubahan atas Undang-Undang Nomor 24 tahun 2003 tentang Mahkamah Konstitusi, menyatakan bahwa Mahkamah Konstitusi berwenang mengadili pada tingkat pertama dan terakhir yang putusannya bersifat final untuk:

a. Menguji Undang-Undang terhadap Undang-Undang Dasar Negara Republik Indonesia tahun 1945

b. Memutus sengketa kewenangan lembaga negara yang kewenangannya diberikan oleh Undang-Undang Dasar Negara Republik Indonesia tahun 1945.

c. Memutus pembubaran partai politik.

d. Memutus perselisihan tentang hasil pemilihan umum.

Dapat disimpulkan bahwa, sifat daripada putusan pra peradilan tersebut adalah bersifat permanen atau tetap, artinya bukan untuk sementara waktu, berlangsung lama, dan tidak dapat diubah. Hal ini disebabkan karena sifatnya yang final dan mengikat itu tadi. ${ }^{21}$ Putusan ini mengadili permohonan Praperadilan yang telah memberi kesempatan kepada Kuasa Termohon untuk menyusun dan membacakan jawaban terhadap dalil-dalil maupun alasan-alasan yang dijadikan dasar bagi Pemohon mengajukan permohonan Praperadilan ini yang telah diajukan kepada Komisi Pemberantasan Korupsi (KPK) yang tentunya tidak lain dimaksudkan untuk tegaknya hukum dan perlindungan hak-hak Pemohon selaku lembaga swadaya masyarakat yang peduli dengan upaya pemberantasan korupsi.

Upaya yang Pemohon ajukan ini merupakan bagian penting dari proses penegakan hukum sebagaimana yang diatur dalam Kitab Hukum Acara Pidana (KUHAP) yang perlu

21 http://www.hukumonline.com/klinik/detail/1t526f5f2e256c2/sifat-dan-keberlakuan-putusanmahkamah-konstitusi diakses pada hari selasa tanggal 7 maret 2017 pukul 13.30 
disampaikan, bahwa Praperadilan merupakan sarana pengawasan horizontal atas tindakantindakan yang dilakukan oleh penyidik dan penuntut umum dalam melakukan upaya paksa seperti penangkapan, penahanan, penyitaan, penghentian penyidikan dan penghentian penuntutan; Selanjutnya, Termohon akan memberikan Jawaban/Tanggapan terbatas pada dalil atau alasan-alasan yang diajukan oleh Pemohon yang berkaitan langsung dengan masalah yuridis tindakan yang dilakukan oleh Termohon, dimana tanggapan/jawaban terhadap seluruh materi permohonan Praperadilan yang diajukan oleh Pemohon dalam permohonan Praperadilan Nomor: 24/Pid.Pra/2018/PN.Jkt.Sel, maka Termohon terlebih dahulu mengajukan Eksepsi atas permohonan Praperadilan, sebagai berikut:

a. Dalam eksepsi terhadap permohonan pra peradilan nebis in idem.

Asas nebis in idem dalam praktek peradilan telah mengalami perkembangan penafsiran, antara lain: "Ada atau tidaknya asas nebis in idem tidak semata-mata ditentukan oleh para pihak saja, melainkan terutama bahwa obyek dari sengketa sudah diberi status oleh keputusan Pengadilan Negeri yang lebih dulu dan telah mempunyai kekuatan pasti dan alasannya sama. Putusan Mahkamah Agung tanggal 20 Mei 2002 No. 1226K/Pdt/2001, yang kaidah hukumnya yaitu: "Meski kedudukan subyeknya berbeda tetapi obyek sama dengan perkara yang diputus terdahulu dan berkekuatan hukum tetap maka gugatan dinyatakan nebis in idem"; Pokok perkara dalam Praperadilan yang diajukan Pemohon saat ini (Perkara No.24/Pid.Pra/2018/PN.JKT.Sel. tanggal 01 Maret 2018) adalah SAMA dengan perkara Praperadilan Nomor: 12/Pid.Prap/2016/PN.Jkt.Sel. yang telah berkekuatan hukum tetap, baik subyek maupun obyek perkara.

Obyek permohonan terkait penghentian penyidikan secara materil tidak sah dalam penanganan perkara Bank Century; Dalam perkara Praperadilan Nomor: 12/Pid.Prap/2016/ PN.Jkt.Sel. tersebut, Hakim Praperadilan telah memeriksa substansi permohonan praperadilan yang diajukan oleh Pemohon memberikan pertimbangan diantaranya pada halaman 24 Putusan Pengadilan Negeri Jakarta Selatan Nomor: 12/Pid.Prap/2016/ PN.Jkt.Sel., sebagai berikut: Menimbang, bahwa namun pada faktanya dalam persidangan praperadilan ini tidak ada bukti Termohon telah melakukan penyelidikan dan/atau penyidikan sehingga secara logika tidak ada penyelidikan maupun penyidikan yang dihentikan oleh Termohon”.

Amar Putusan dari Perkara Praperadilan Nomor: 12/Pid.Prap/2016/ PN.Jkt.Sel., adalah sebagai berikut: Mengadili 1. Menolak Permohonan Praperadilan Pemohon untuk seluruhnya; 2. Menetapkan biaya perkara sebesar nihil; Demikianlah, diputuskan pada hari Kamis, tanggal 10 Maret 2016 oleh Hakim Martin Fonto Bidara, SH, Hakim pada Pengadilan Negeri Jakarta Selatan, putusan mana diucapkan oleh Hakim tersebut dalam sidang yang terbuka untuk umum pada hari itu juga dengan didampingi Nining Hendarti SH, Panitera Pengganti serta dihadiri Pemohon dan Termohon; Berdasarkan hal tersebut, dengan demikian telah dilakukan pemeriksaan terhadap obyek sengketa yang memiliki subtansi yang sama, dan juga telah diadili dan diputus oleh Hakim, sehingga asas nebis in idem secara mutlak telah terpenuhi; Pada prinsipnya, asas nebis in idem berfungsi untuk menjaga kepastian hukum, mencegah terjadinya penilaian yang saling bertentangan atas obyek sengketa yang telah diberikan status hukum tertentu dalam putusan Pengadilan sebelumnya yang telah berkekuatan hukum tetap; Sejalan dengan hal tersebut, Mahkamah Agung menerbitkan Surat Edaran Mahkamah Agung Nomor 03 Tahun 2002 tentang Penanganan Perkara yang Berkaitan dengan Asas nebis in idem, angka 2 huruf c menyebutkan: "Majelis Hakim wajib mempertimbangkan, baik pada 
putusan eksepsi maupun pada pokok perkara, mengenai perkara serupa yang pernah diputus di masa lalu."

Berdasarkan hal tersebut, oleh karena subjek dan objek dalam perkara permohonan Praperadilan aquo adalah sama dengan subjek dan objek dalam perkara Praperadilan Nomor: 12/Pid.Prap/2016/ PN.Jkt.Sel. yang telah diputus oleh Hakim pada Pengadilan Negeri Jakarta Selatan (Yang Mulia Bapak Hakim Matin Fonto Bidara, SH), yang telah berkekuatan hukum tetap, maka permohonan Praperadilan aquo telah melanggar asas nebis in idem; Sehubungan dengan hal tersebut, untuk menghindari adanya pertentangan Putusan Hakim atas obyek sengketa yang sama yang telah diperiksa dan diputus terdahulu oleh Hakim lainnya, maka sudah selayaknya apabila Hakim Praperadilan aquo untuk tidak lagi memeriksa dan memberikan putusan atas Perkara Praperadilan aquo, dengan menyatakan bahwa asas nebis in idem telah terpenuhi. Dengan demikian, sudah selayaknya permohonan praperadilan aquo ditolak atau setidaktidaknya harus dinyatakan tidak dapat diterima (niet ontvankelijke verklaard).

Ketidaksatuan pemahaman di kalangan hakim pada lembaga Praperadilan mengenai aspek penetapan tersangka masuk atau tidaknya menjadi kewenangan Praperadilan tentu saja menimbulkan ketidakpastian hukum di masyarakat. Hal ini tentu saja sangat merugikan masyarakat, terutama para pencari keadilan yang ingin menguji keabsahan penetapan tersangkanya, karena semuanya akan sangat bergantung kepada subjektifitas masing-masing hakim dan keberuntungan dari masing-masing pemohon. Kalau beruntung, maka akan mendapatkan hakim yang akan menerima pemeriksaan keabsahan penetapan tersangka dalam praperadilan. Kalau tidak beruntung, maka hakim akan menolak hal tersebut sebagai objek praperadilan. Disini kita bisa melihat bahwa tidak ada kepastian hukum megenai status keabsahan penetapan tersangka tersebut, apakah bisa diuji di praperadilan, atau tidak. ${ }^{22}$

Hal yang demikian tentu tidak mencerminkan apa yang menjadi tujuan hukum itu sendiri. Adapun tujuan dari hukum adalah untuk memperoleh keadilan, kepastian dan kemanfaatan hukum. Tujuan merupakan sebuah sasaran yang hendak dicapai untuk hukum itu sendiri. Pada dasarnya, hukum bertujuan untuk menciptakan tatanan masyarakat yang tertib, aman, tenteram dan adanya keseimbangan dalam kehidupan bermasyarakat. Dengan tercapainya ketertiban dalam bermasyarakat diharapkan kepentingan manusia sebagai subjek hukum akan terlindungi tanpa terbentur dengan kepentingan sesamanya. ${ }^{23}$ Oleh sebab itu hukum haruslah bertugas untuk membagi hak dan kepentingan manusia, membagi wewenang, dan mengatur cara memecahkan atau menyelesaikan jika terjadi permasalahan dalam mempertahankan hak dan kewajiban tersebut.

Hukum yang baik setidaknya harus mengandung tiga hal pokok yang hendak dicapai yaitu keadilan, kemanfaatan dan kepastian hukum. Terkait kepastian hukum, hal tersebut merupakan harapan para pencari keadilan terhadap kesewenang-wenangan aparat penegak hukum yang terkadang menunjukkan arogansinya dalam menjalankan tugas penegakan hukum, karena dengan adanya kepastian hukum, maka masyarakat akan memperoleh kejelasan mengenai hak dan kewajibannya menurut hukum. Jadi, setiap orang akan tau apa yang harus diperbuat, mana perbuatan yang benar dan yang salah. Kepastian hukum berarti

\footnotetext{
${ }^{22} \mathrm{https}$ ///kanggurumalas.com/2015/06/10/praperadilan-atas-sah-tidaknya-penetapan-tersangkaperjudian-hukum-yang-diterbiarkan/ diakses pada hari selasa tanggal 7 maret 2017 pukul 14.50

${ }^{23}$ Zaeni Asyhadie, Arief Rahman, 2012, Pengantar Ilmu Hukum, Jakarta, PT Raja Grafindo, hlm. 
merupakan permasalahan ketepatan hukumnya, subjek dan objek serta ancaman hukumannya.

Perbedaan-perbedaan pandangan oleh para hakim dalam menanggapi kasus-kasus praperadilan dengan permohonan serupa seperti yang telah dijabarkan di atas, sudah jelas tidak mencerminkan keadilan, kepastian dan kemanfaatan hukum. Dari putusan yang bersifat subjektif tersebut tentu hanya menguntungkan bagi kalangan tertentu yang mendapatkan putusan yang diputus oleh hakim yang juga setuju mengenai penambahan aspek sah atau tidaknya status tersangka di dalam objek Praperadilan. Maka ketidakseragaman tersebutlah yang kemudian membingungkan masyarakat sebagai pencari keadilan.

Lembaga Praperadilan sendiri dibentuk dengan tujuan untuk tegaknya hukum, kepastian hukum dan terlindunginya hak-hak dari tersangka. Sebab, semua upaya paksa yang dilalukan oleh penyidik ataupun penuntut umum mulai dari penangkapan, penggeledahan, penyitaan, penahanan, penuntutan penghentian penyidikan dan penuntutan haruslah sesuai dengan peraturan perundang-undangan. Praperadilan diharapkan mampu memberikan pengawasan terhadap pemeriksaan pendahuluan di tingkat penyidikan dan juga penuntutan.

Heber Anggara Pandapotan, auditor hukum BPKP Maluku berpendapat di dalam jurnalnya yang berjudul Praperadilan Status Tersangka, bukti rusaknya Integrated Criminal Justice System di Indonesia bahwa ada beberapa dampak negatif dari lahirnya putusan hakim yang mengikuti putusan Hakim Sarpin dengan mengatur penetapan status tersangka di dalam objek Praperadilan, yaitu: ${ }^{24}$

a. Putusan Praperadilan akan membuka penafsiran ekstensif setiap orang yang ditetapkan sebagai tersangka oleh aparat penegak hukum. Padahal larangan pertama dalam penafsiran suatu peraturan perundang-undangan adalah dengan melakukan penafsiran ekstensif. Penafsiran ekstensif yang dimaksud dalam hal ini adalah penafsiran yang di luar atau melebihi makna dari norma itu sendiri (melebihi original intent).

b. Dengan adanya putusan ini akan ada ribuan sidang Praperadilan yang akan diselenggarakan karena adanya gugatan yang dilayangkan oleh para tersangka yang mencoba mencari upaya hukum untuk bisa keluar dari proses justisia. Padahal para penegak hukum sudah cukup bukti permulaan untuk menetapkan seseorang menjadi tersangka.

c. Praperadilan tidak lagi bertitik berat pada pembuktian formil terhadap sah atau tidaknya penangkapan, penahanan, penghentian penyidikan atau penuntutan, permintaan ganti kerugian dan rehabilitasi, namun mulai masuk kepada materi buktibukti permulaan yang dimiliki oleh aparat penegak hukum. Padahal di dalam Pasal 82 ayat (1) huruf c KUHAP mengatakan bahwa pemeriksaan Praperadilan dilakukan secara cepat dan selambat-lambatnya 7 hari kerja harus ada putusan. Sehingga sangatlah tidak tepat menempatkan pembuktian validitas alat bukti ataupun bukti permulaan penegak hukum dalam sidang Praperadilan yang seharusnya diperiksa dalam persidangan biasa.

d. Menciptakan snowball effect dalam dunia penegakan hukum di Indonesia. Seperti contoh, terhadap objek Praperadilan yang lain, apabila disetujui oleh hakim, tidak menghentikan proses perkara. Namun bagaimana jika Praperadilan penetapan status tersangka dikabulkan oleh hakim. Kemudian bagaimana jika KPK yang melakukan

${ }^{24}$ http://www.bpkp.go.id/public/upload/unit/maluku/files/PRAPERADILAN\%20PENETAPAN\%20 STATUS\%20TERSANGKA,\%20BUKTI\%20RUSAKNYA\%20CRIMINAL\%20JUSTICE\%20SYSTEM\%2 0DI\%20INDONESIA.pdf diakses pada 12 April 2017 pukul 08.55 WIB 
penetapan tersangka tersebut, padahal kita mengetahui KPK tidak dapat menghentikan perkara yang telah masuk ke dalam tahap penyidikan. Mungkin aparat penegak hukum dapat mensiasatinya dengan tafsiran lain untuk tetap melanjutkan kasus tersebut. Namun hal ini tentu semakin menggiring sistem pemidanaan kita kepada posisi yang tidak seharusnya dilakukan.

e. Melanggar asas-asas umum peradilan pidana, seperti peradilan cepat, sederhana dan biaya ringan.

\section{Kesimpulan}

Dasar yang menjadi pertimbangan hakim meliputi dasar pertimbangan yuridis dan dasar pertimbangan non yuridis. Dasar pertimbangan yang bersifat yuridis adalah pertimbangan hakim yang didasarkan pada fakta yuridis dalam persidangan dan oleh ketentuan undang-undang harus dimuat dalam putusan hakim, sedangkan dasar pertimbangan yang bersifat non yuridis adalah pertimbangan hakim yang hanya bertitik tolak pada dampak yang merugikan dan merusak tatanan dalam kehidupan bermasyarakat, berbangsa dan bernegara.

Implikasi hukum yang terlihat dari keberagaman putusan-putusan praperadilan yang lahir adalah terjadinya ketidakpastian hukum dan merugikan bagi para pencari keadilan. Sebab dikabulkannya atau ditolaknya permohonan Praperadilan tersebut bersifat subjektif, artinya tergantung Hakim yang memutusnya apakah sependapat dengan putusan Hakim atau tidak mengenai penetapan status tersangka di dalam objek Praperadilan. Hal tersebut sama sekali tidak mencerminkan tujuan daripada hukum itu sendiri, yang diharapkan oleh masyarakat untuk memperoleh keadilan, kemanfaatan dan kepastian hukum. Namun dengan dikeluarkannya putusan Mahkamah Konstitusi mengenai penambahan aspek sah atau tidaknya status tersangka menjadi objek praperadilan nantinya berdampak kepada lamanya proses peradilan dan juga secara otomatis menambah kewenangan daripada hakim praperadilan untuk menangani perkara mengenai sah atau tidaknya penetapan tersangka.

\section{DAFTAR PUSTAKA}

Atmasasmita, Romli, 1996, Sistem Peradilan Pidana: Perspektif Eksistensialisme dan Abolisionisme, Bandung, Binacipta.

Dirdjosisworo, Soedjono, 1984, Filsafat Peradilan Pidana dan Perbandingan Hukum, Bandung, Armico.

Hamzah, Andi. 2008, Hukum Acara Pidana Indonesia, Jakarta, Sinar Grafika.

Harahap, M. Yahya, 2010, Pembahasan Permasalahan dan Penerapan KUHAP (Pemeriksaan Sidang Pengadilan, Banding, Kasasi, dan Peninjauan Kembali), Jakarta, Sinar Grafika.

Kitab Undang-Undang Hukum Pidana.

http://makassar.lan.go.id/index.php/survei/refleksi/750-putusan-mk-penetapan-tersangkapenggeledehan-dan-penyitaan-masuk-dalam-ranah-hukum-praperadilan, diakses pada tanggal 4 November 2016.

https://nasional.kompas.com, Hakim Gugurkan Gugatan Pra Peradilan Setya Novanto, diakses pada tanggal 2 Mei 2018 
https://nasional.sindonews.com/read/1299034/18/bagaimana-kpk-menyikapi-putusan-praperadilan1524088716, Bagaimana KPK Menyikapi Putusan Praperadilan ?, diakses pada tanggal 2 Mei 2018.

https://kbbi.web.id/sarana, diakses pada tanggal 2 Mei 2018.

http://srihartinaap3.blogspot.co.id/2014/09/sarana-dan prasarana.html, diakses pada tanggal 2 Mei 2018 John Rawls, Teori Keadilan, https:/www.researchgate.net /publication/ 308803683_Teori_Keadilan_John_Rawls_John_Rawls\%27_Theory_of_Justice, diakses pada tanggal 06 May 2018.

Koren, Henry J., 1995, An Introduction To The Philosophy Of Animate Nature, Amazon, Literary Licensing, LLC.

Luqman, Loebby, 2002, Pra Peradilan di Indonesia, Jakarta, Ghalia Indonesia.

Muhammad, Rusli, 2011, Sistem Peradilan Pidana Indonesia: Dilengkapi Dengan 4 Undang-undang di Bidang Sistem Peradilan Pidana, Yogyakarta, UII Press.

Muladi, Kapita Selekta Sistem Peradilan Pidana, Semarang, Badan Penerbit Universitas Diponegoro.

Pasha, Mustafa Kamal, 2003, Pancasila Dalam Tinjauan Historis dan Filosofis, Yogyakarta, Citra Karsa Mandiri.

Prodjodikoro, Wirjono, 1981, Asas-Asas Hukum Pidana, Jakarta, Eresco.

Putusan Mahkamah Konstitusi Nomor 21/PUU-XII/2014.

Raharjo, Satjipto, 2009, Penegakan Hukum Suatu Tinjauan Sosiologis, Yogyakarta.

Reksodiputro, Mardjono, 1994, Kriminologi dan Sistem Peradilan Pidana, Jakarta, Pusat Pelayanan Keadilan dan Pengabdian Hukum UI.

Sholehuddin, M, 2003, Sistem Sanksi Dalam Hukum Pidana Ide Dasar Double Track System Dan Implementasinya, Jakarta, PT Raja Grafindo Persada.

Soekanto, Soerjono, 2008, Pengenalan Penelitian Hukum, Jakarta, UI Press. Jakarta, Rajawali Pers.

Soeroso, R., 2011, Pengantar Ilmu Hukum, Jakarta, Sinar Grafika.

Suseno, Frans Magnis, 1988, Etika Politik, Jakarta, Gramedia.

Tanusubroto, S., 1983, Peranan Pra Peradilan Dalam Hukum Acara Pidana, Bandung, Alumni.

Undang-Undang Dasar Negara Republik Indonesia Tahun 1945.

Undang-Undang No. 48 Tahun 2009 tentang Pokok-Pokok Kekuasaan Kehakiman.

Undang-undang Nomor 8 Tahun 1981 Tentang Hukum Acara Pidana. 